\title{
A!
}

This is an electronic reprint of the original article.

This reprint may differ from the original in pagination and typographic detail.

Nguyen, Minh-Kha; Nguyen, Vu Hoang; Natarajan, Ashwin Karthick; Huang, Yike; Ryssy, Joonas; Shen, Boxuan; Kuzyk, Anton

\section{Ultrathin Silica Coating of DNA Origami Nanostructures}

Published in:

Chemistry of Materials

DOI:

10.1021/acs.chemmater.0c02111

Published: $11 / 08 / 2020$

\section{Document Version}

Publisher's PDF, also known as Version of record

Published under the following license:

CC BY

Please cite the original version:

Nguyen, M-K., Nguyen, V. H., Natarajan, A. K., Huang, Y., Ryssy, J., Shen, B., \& Kuzyk, A. (2020). Ultrathin Silica Coating of DNA Origami Nanostructures. Chemistry of Materials, 32(15), 6657-6665.

https://doi.org/10.1021/acs.chemmater.0c02111

This material is protected by copyright and other intellectual property rights, and duplication or sale of all or part of any of the repository collections is not permitted, except that material may be duplicated by you for your research use or educational purposes in electronic or print form. You must obtain permission for any other use. Electronic or print copies may not be offered, whether for sale or otherwise to anyone who is not an authorised user. 


\title{
Ultrathin Silica Coating of DNA Origami Nanostructures
}

\author{
Minh-Kha Nguyen,* Vu Hoang Nguyen, Ashwin Karthick Natarajan, Yike Huang, Joonas Ryssy, \\ Boxuan Shen, and Anton Kuzyk*
}

Cite This: Chem. Mater. 2020, 32, 6657-6665

Read Online

\section{ACCESS | Lill Metrics \& More | 回 Article Recommendations | S1 Supporting Information}

ABSTRACT: The DNA origami technique has emerged as one of the most versatile bottom-up nanofabrication methods due to its ability to construct well-defined complex three-dimensional nanostructures and guide assembly of functional nanoscale objects with unprecedented precision, high yields, and controlled stoichiometry. Nonetheless, limited compatibility with biologically relevant fluids and typical solvents utilized in nanofabrication often restricts applications of DNA origami-based assemblies and devices. Here we present an approach for coating DNA origami structures with silica. By careful adjustment of

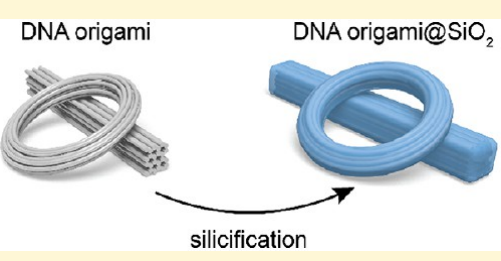
experiment parameters, we achieved reproducible growth of ultrathin silica shell in solution without agglomeration or deformation of DNA origami structures. The silica-coated structures are stable in water and exhibit an increased resistivity to nuclease-mediated degradation. In addition, the coated structures preserve their structural integrity in polar organic solvents. We anticipate that our results will aid further advancement of DNA origami techniques as the nanofabrication method.

\section{INTRODUCTION}

Nucleic acids, proteins, carbohydrates, and lipids are four fundamental molecules of life and excellent building blocks for assembly of functional nanoarchitectures. ${ }^{1,2}$ Among them, DNA has attracted substantial interest for fabrication of artificial molecular assemblies due to the simplicity, specificity, and programmability of Watson-Crick base-pairing and the ability to generate well-defined three-dimensional (3D) structures with tailored morphology and chemical addressability. ${ }^{3,4}$ In particular, the DNA origami technique ${ }^{5}$ provides an efficient strategy for engineering of complex nanostructures with arbitrarily prescribed shapes and rich types of hierarchical organizations. ${ }^{6,7}$ In addition, DNA origami structures have been widely used as templates for assembly of nanoparticles, $^{8-11}$ proteins, ${ }^{12-15}$ fluorescent dyes, ${ }^{16-18}$ polymers, ${ }^{19,20}$ and so on. Furthermore, applications of DNA origami constructs as molds ${ }^{21,22}$ and masks ${ }^{23,24}$ for nanofabrication have been proposed. Precise control over the nanoscale morphology and the ability to arrange multiple functional nanoscale components with high accuracy have enabled applications of the DNA origami technique in various fields, e.g., biomedical research, ${ }^{25,26}$ biophysics, ${ }^{27-29}$ biosensing, $^{30-33}$ nanophotonics, ${ }^{34-39}$ nanorobotics, ${ }^{40,41}$ and drug delivery. ${ }^{42,43}$ Despite the great promise of utility, ${ }^{44-46}$ the applicability of DNA origami-based assemblies and devices is often restricted by the limited compatibility with the biologically relevant fluids and common solvents employed in nanofabrication. For biomedical applications, enhanced stability of DNA origami structures against magnesium ion depletion and nuclease-mediated degradation have been achieved by using various approaches, including covalent cross-linking ${ }^{47}$ and stabilization through coating with positively charged species ranging from proteins ${ }^{48,49}$ to polymers ${ }^{50,51}$ and oligolysine conjugates. ${ }^{52,53}$ Reaching compatibility with nanofabrication relevant organic solvents remains a significant challenge. DNA origami constructs can preserve their structural integrity after exposure to common organic solvents after deposition on surfaces but not in solution. ${ }^{34}$

Silica coating has recently attracted significant interest as a protection strategy for the stability enhancement of DNA origami-based assemblies ${ }^{55}$ and as an approach for transferring unprecedented control over the nanoscale morphology offered by the DNA origami technique into inorganic materials. ${ }^{56-58}$ Thin layers of amorphous silica were grown on substrate deposited 2D and 3D DNA origami constructs, and silica coating significantly improved the mechanical properties of the origami structures. ${ }^{56,57}$ A modified Stöber method was applied for DNA origami-templated silica growth in a low- $\mathrm{Mg}^{2+}$ solution. ${ }^{55}$ Despite important advancements, the demonstrated approaches have serious limitations, e.g., an incomplete silica coating due to the substrate-based reactions ${ }^{56}$ or significant agglomeration and structural deformation of origami structures after silica coating. ${ }^{55}$ Achieving controlled silicification in solution with well-dispersed nondeformed silica-coated DNA origami structures has remained challenging. Here, we demonstrate an approach that enables fabrication of DNA origami@SiO $\mathrm{S}_{2}$ nanostructures via well-established silica surface chemistry. Our method combines tailored response to environmental changes and precursor concentrations with

Received: May 19, 2020

Revised: July 14, 2020

Published: July 15, 2020 
the growth of silica on 3D DNA origami structures. Welldispersed DNA origami@SiO $\mathrm{Si}_{2}$ structures in solution were achieved with uniform coating and ultrathin silica shells. Furthermore, after the coating the DNA origami@SiO structures were stable in DI water (for at least 10 months) and in pure IPA (for at least 3 days) and resisted nucleasemediated degradation.

\section{EXPERIMENTAL SECTION}

Materials. Single-stranded circular DNA scaffold strands (p7560 and p7249) were purchased from tilibit nanosystems. DNA staple strands were purchased from biomers.net and Thermo Fisher Scientific. Buffers and other chemicals were purchased from either Sigma-Aldrich or Fisher Scientific. All reagents were commercially available and used without any further purification. Type I ultrapure deionized (DI) water, from a Milli-Q system, was used for all experiments.

Assembly of DNA Origami. The DNA origami templates were designed by using caDNAno software. ${ }^{59}$ Two different 3D DNA origami nanostructures, i.e., 24 helix bundle $(24 \mathrm{HB})$ and 13 helix ring (13HR), were used (Scheme 1). The sequences of the staple strands

\section{Scheme 1. Schematic Illustration of the Silica Coating of} DNA Origami Structures with APTES, TMAPS, and TEOS

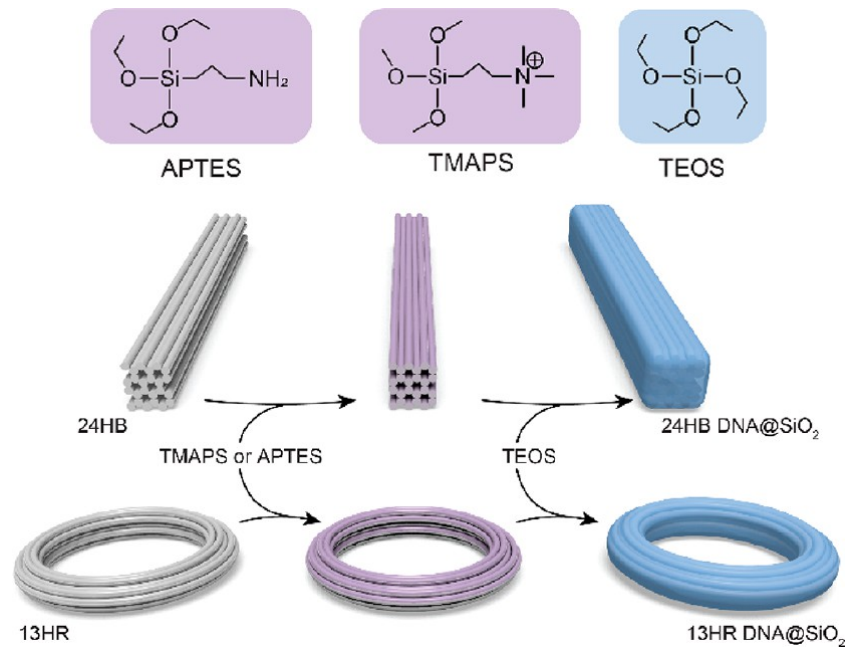

and the designs are reported in the Supporting Information (Figures S1, S2 and Tables S1, S2). For the fabrication of the DNA origami structures, the scaffold ( $20 \mathrm{nM}$ p 7560 for $24 \mathrm{HB}$ and $10 \mathrm{nM}$ p 7249 for $13 \mathrm{HR}$ ) was mixed with the relevant staples (10 times molar excess) in $1 \times \mathrm{TE}$ buffer together with 15 and $10 \mathrm{mM} \mathrm{MgCl}$ for $24 \mathrm{HB}$ and $13 \mathrm{HR}$, respectively. The solution mixtures were thermally annealed from 80 to $20{ }^{\circ} \mathrm{C}$ (Table S3). After the annealing procedure, the $13 \mathrm{HR}$ structures were purified by $1 \%$ agarose gel electrophoresis (AGE) in $0.5 \times \mathrm{TBE}, 11 \mathrm{mM} \mathrm{MgCl}_{2}$, and $1 \times$ Sybrsafe and concentrated by poly(ethylene glycol) (PEG) precipitation. ${ }^{60}$ The 24HB structures were purified and concentrated by PEG. After purification, the DNA origami nanostructures were dispersed in 15 $\mathrm{mM}$ magnesium acetate (MgAc) buffer-free aqueous solution and stored at $4{ }^{\circ} \mathrm{C}$. Transmission electron microscopy (TEM) images of $24 \mathrm{HB}$ and $13 \mathrm{HR}$ origami structures after fabrication and purification can be found in the Supporting Information (Figure S3).

Silica Coating of DNA Origami. Primary Coating in an Aqueous Solution of $15 \mathrm{mM}$ MgAc. The stock precursors, i.e., (3aminopropyl)triethoxysilane (APTES), $\mathrm{N}$-[3-(trimethoxysilyl)propyl]-N,N,N-trimethylammonium chloride (TMAPS), and tetraethyl orthosilicate (TEOS), were freshly diluted in $15 \mathrm{mM} \mathrm{MgAc}$ aqueous solution (the same $\mathrm{MgAc}$ concentration as used to store DNA origami) and used within $3 \mathrm{~min}$ of preparation. The concentrations of coupling agents (APTES or TMAPS) were calculated according to the molar ratio to the phosphate groups in DNA origami $(\mathrm{C} / \mathrm{P})$. The DNA origami sample $(20 \mu \mathrm{L})$ in $15 \mathrm{mM}$ MgAc solution ( $\mathrm{pH} \sim 6$ or adjusted to $\mathrm{pH} 9$ by $50 \mathrm{mM} \mathrm{NaOH})$ was mixed with $2.4 \mu \mathrm{L}$ of the coupling agent and shaken at $500 \mathrm{rpm}$ for 1 $\mathrm{h}$ at room temperature. Then, $2.8 \mu \mathrm{L}$ of TEOS was added, followed by $\mathrm{pH}$ adjustment to 9 using $10 \mathrm{mM} \mathrm{NaOH}$ (without adjustment for the investigation at $\mathrm{pH}$ 6). The concentrations of TEOS were calculated according to the molar ratio to the phosphate groups in DNA origami $(\mathrm{T} / \mathrm{P})$. After shaking at $500 \mathrm{rpm}$ for up to the investigated days, the sample was washed twice with DI water by using an Amicon Ultra-0.5 $\mathrm{mL}$ centrifugal filter (MWCO $100 \mathrm{kDa}$ ) at a speed of $8000 \mathrm{rcf}$ for 3 min. The origami structures after the primary coating are termed DNA@SiO ${ }_{2}-1$.

Secondary Coating in a Mixture of Isopropanol and Water. DNA origami structures after the primary silica coating $\left(\mathrm{DNA} @ \mathrm{SiO}_{2-}\right.$ $1,2 \mu \mathrm{L}$ ) were diluted in $20 \% \mathrm{v} / \mathrm{v}$ of isopropanol (IPA) in water, and the $\mathrm{pH}$ was adjusted to 10.8 by $28 \% \mathrm{w} / \mathrm{w} \mathrm{NH}_{4} \mathrm{OH}$ solution. After that, $1 \mu \mathrm{L}$ of fresh TEOS with a calculated concentration in IPA was added and shaken at $500 \mathrm{rpm}$ for $24 \mathrm{~h}$ at room temperature. After the secondary coating the structures were purified and concentrated by using centrifugal filters as after the primary coating. The products were stored at $4{ }^{\circ} \mathrm{C}$. The origami structures after the secondary coating are termed DNA@SiO -2 .

Stability Tests. Stability of DNA Nanostructures in Water and Organic Solvent. After purification, the DNA origami and DNA@ $\mathrm{SiO}_{2}$ nanostructures were resuspended in DI water or IPA to a final concentration of $\sim 0.6 \mathrm{nM}$. The samples in water and in IPA were kept at $4{ }^{\circ} \mathrm{C}$ and room temperature, respectively, for various durations and imaged by TEM.

Nuclease Degradation Assay. DNA origami structures with and without silica coating were diluted to a final concentration of $1 \mathrm{nM}$ in DNase reaction buffer containing different amounts of DNase I. The samples were incubated at $37^{\circ} \mathrm{C}$ for $3 \mathrm{~h}$ and analyzed by using AGE and TEM.

Characterization. UV-Vis Spectroscopy. The concentration of the purified DNA origami structures was estimated by using UV-vis absorption spectroscopy and an extinction coefficient of $1.3 \times 10^{8}$ $\mathrm{M}^{-1} \mathrm{~cm}^{-1}$ at $260 \mathrm{~nm}^{6}$

TEM Imaging. The DNA origami nanostructures were imaged by using either FEI Tecnai F12 or F20 electron microscopes operated at 120 or $200 \mathrm{kV}$, respectively. For imaging, the sample solutions $(5 \mu \mathrm{L})$ were adsorbed onto a glow discharged carbon-film-coated copper grids for $5 \mathrm{~min}$ and then wiped away, followed by staining with a $0.5 \%$ uranyl formate solution containing $25 \mathrm{mM} \mathrm{NaOH}$ for $20 \mathrm{~s}$.

Atomic Force Microscopy (AFM) Imaging. The height of DNA origami nanostructures (with and without silica) was obtained by using a Dimension Icon AFM (Bruker) equipped with a fluid cell and operated in ScanAsyst mode. ScanAsyst-Fluid+ probes (Bruker) were used for imaging. For AFM characterization, $5 \mu \mathrm{L}$ of $100 \mathrm{mM} \mathrm{NiCl}$ in $1 \times$ TE was deposited onto freshly cleaved mica (Ted Pella) for 1 $\mathrm{min}$. The excess liquid was removed by filter paper. After that, $5 \mu \mathrm{L}$ of sample was deposited for $4 \mathrm{~min}$, followed by addition of $120 \mu \mathrm{L}$ of 10 mM NiCl 2 in $1 \times$ TE. $40 \mu \mathrm{L}$ of $10 \mathrm{mM} \mathrm{NiCl}_{2}$ in $1 \times \mathrm{TE}$ was added to the AFM probe.

\section{RESULTS AND DISCUSSION}

Primary Silica Growth in MgAc Solution. The silica growth on DNA origami templates proceeds in two steps. First, an alkylalkoxysilane with a positively charged group is used as a coupling agent that electrostatically associates with the negatively charged phosphate backbone of DNA. Then, the silanol groups of the coupling agent serve as a co-condensation sites for TEOS to form silica shell around the DNA structures (Scheme 1). We systematically investigated the effects of different conditions, e.g., type of coupling agent, $\mathrm{pH}$, silica precursors ratios to phosphate groups on DNA structures, silica growth time, and MgAc and DNA origami concentration, on the silica growth process. We optimized the experimental 
conditions on 24HB (Scheme 1, Figures S1 and S3a) to obtain a well-dispersed DNA nanostructures with uniform silica coating.

First, we characterized the influence of the coupling agents and the initial $\mathrm{pH}$. TMAPS has been widely employed as an initiator species for the silica growth on dsDNA or DNA structures in most of the previous works. ${ }^{55-58,62-66}$ Less attention has been given to the effects of different coupling agents with respect to controlling a uniform silica coating on DNA origami. Besides TMAPS, we tested APTES, i.e., a significantly less hazardous coupling agent, as an alternative. The interaction of the coupling agent with the DNA backbone and the subsequent condensation of TEOS can be strongly influenced by $\mathrm{pH}^{58}$ In general, the condensation reaction of silanol groups occurs before the silane hydrolysis is completed, and the $\mathrm{pH}$ strongly affects the polymerization rate of $\mathrm{SiO}_{2}{ }^{67}$ On the other hand, the DNA origami structures are stable in the $\mathrm{pH}$ range between 5.5 and 9.5..$^{54,68}$ To eliminate the possible negative effects of buffers' components on the silica coating process, we dispersed the DNA origami structures in buffer-free aqueous solution of $15 \mathrm{mM} \mathrm{MgAc}(\mathrm{pH} \sim 6)$ and adjusted the $\mathrm{pH}$ if necessary. The effects of different coupling agents and $\mathrm{pH}$ on achieving well-dispersed DNA origami@ $\mathrm{SiO}_{2}$ core-shell nanostructures are shown in Figure 1.

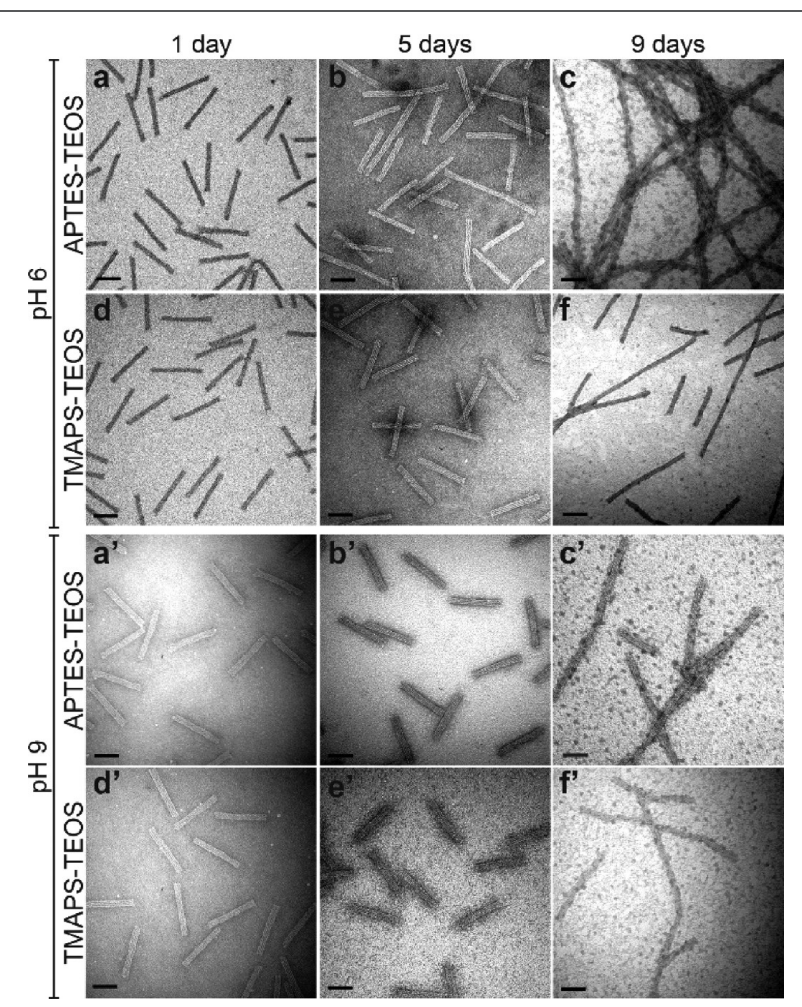

Figure 1. APTES and TMAPS mediated silica growth on $12 \mathrm{nM}$ $24 \mathrm{HB}$ in aqueous solution of $15 \mathrm{mM} \mathrm{MgAc}$ under different initial $\mathrm{pH}$ values. The molar ratios of $\mathrm{C} / \mathrm{P}=3: 1$ and $\mathrm{T} / \mathrm{P}=20: 1$ were used. Scale bars: $50 \mathrm{~nm}$.

Interestingly, after a 5 day silicification at $\mathrm{pH} 6$, some of $24 \mathrm{HB}$ structures were stacked tip-to-tip in APTES-TEOS coating but not in TMAPS-TEOS (Figure 1b,e). After a 9 day coating, the stacking was present in both APTES-TEOS and TMAPS-TEOS conditions and was more pronounced at $\mathrm{pH} 6$ than at $\mathrm{pH} 9$ (Figure $1 \mathrm{c}, \mathrm{f}$ vs Figure $1 \mathrm{c}^{\prime}, \mathrm{f}^{\prime}$ ). It is known that the hydrolysis rate of alkoxide is faster than the condensation rate at a moderately low $\mathrm{pH} .{ }^{69}$ The ionization state of amine groups in APTES surfaces at a solution $\mathrm{pH}$ is determined by their surface $\mathrm{p} K_{\mathrm{a}}$. Previous studies using contact angle titration and fluorescent nanoparticle adhesion assay have revealed that amino groups from the APTES surfaces have $\mathrm{p} K_{\mathrm{a}} \approx 7.3^{70}$ Solving the Henderson-Hesselbalch equation using this $\mathrm{p} K_{\mathrm{a}}$ value

$$
f_{\mathrm{NH}_{3}^{+}}=\frac{1}{1+10^{\mathrm{pH}-\mathrm{pK}}}
$$

where $f_{\mathrm{NH}_{3}}{ }^{+}$is the fraction of the $-\mathrm{NH}_{3}{ }^{+}$groups in APTES, indicates that the degree of ionization of amino groups in APTES surfaces changes rapidly in the $\mathrm{pH}$ range from 6 to 9 . The amino group of APTES on a surface is fully protonated below $\mathrm{pH} 6$ and nearly neutral above $\mathrm{pH} 9$ (see the Supporting Information for additional discussion on the ionization states of APTES). Typically, silica gels condensed from silanol groups with the presence of aminosilanes exhibit a surface amine-attaching functionality. ${ }^{71}$ In addition, the edges of DNA origami structures are commonly modified with singlestranded DNA (ssDNA) loops or extensions to prevent double-helical blunt-end interactions. ${ }^{72}$ Because of the short persistence length of ssDNA, ${ }^{73}$ this results in a high density of negative charges at the certain edges of DNA origami structures. At $\mathrm{pH} \mathrm{6,} \mathrm{the} \mathrm{strong} \mathrm{interaction} \mathrm{of} \mathrm{positively}$ charged APTES with ssDNA on the short edges of $24 \mathrm{HB}$ structures leads to enhanced tip-to-tip stacking interactions. While the $-\mathrm{N}^{+}\left(\mathrm{CH}_{3}\right)_{3}$ groups of TMAPS are also positively charged, the interaction between $-\mathrm{N}^{+}$and the negative charges of ssDNA could be reduced by the presence of $-\mathrm{CH}_{3}$ groups. Therefore, the stacking of $24 \mathrm{HB}$ in TMAPS-TEOS is lower than in APTES-TEOS. Guided by the results presented in Figure 1, we chose $\mathrm{pH} 9$ and deposition time of 5 days for further experiments.

Next, we investigated the influence of the molar ratio of the coupling silane agent/phosphate group on DNA origami (C/ $\mathrm{P})$. After the coating, the structures were well dispersed at $\mathrm{C} / \mathrm{P}$ ratios of $2: 1$ and $3: 1$ and aggregated at $\mathrm{C} / \mathrm{P}$ ratios larger than 3:1 (Figure 2). To evaluate the role of the coupling agents on the silica deposition process, we also performed coating using TEOS only (Figure S4). Although the silica deposition from TEOS is apparent, the $24 \mathrm{HB}$ formed disordered aggregates not only by tip-to-tip stacking but also by side-to-side binding. It is known that intermediate silica species (from the hydrolysis of TEOS) and DNA origami carry negative charges. ${ }^{4,74}$ The positively charged groups of the coupling agents considerably reduce the repulsion between silanol and phosphate groups and promote uniform growth of the silica network by first assembling around individual DNA strands and subsequently encompassing the entire origami nanostructures. Guided by the results presented in Figure 2, we chose the 3:1 C/P ratio to grow thin silica shell on DNA origami.

The thicknesses of silica shells have been well controlled by adjusting the amount of TEOS and the molar ratio of $\mathrm{H}_{2} \mathrm{O}$ / $\mathrm{TEOS}$ for inorganic nanoparticles@SiO ${ }_{2}\left(\mathrm{NPs} @ \mathrm{SiO}_{2}\right) .^{75-77}$ However, less attention has been given to the effects of molar ratio of the TEOS/phosphate group $(\mathrm{T} / \mathrm{P})$, which is a convenient control parameter for the silica coating of DNA structures. To investigate the effect of $\mathrm{T} / \mathrm{P}$ ratio on the silica growth on origami structures, different TEOS concentrations were used in the growth mixture (Figure 3 ). As the ratio of T/ P increased from 10:1 to $40: 1$, the thickness of the silica shell 


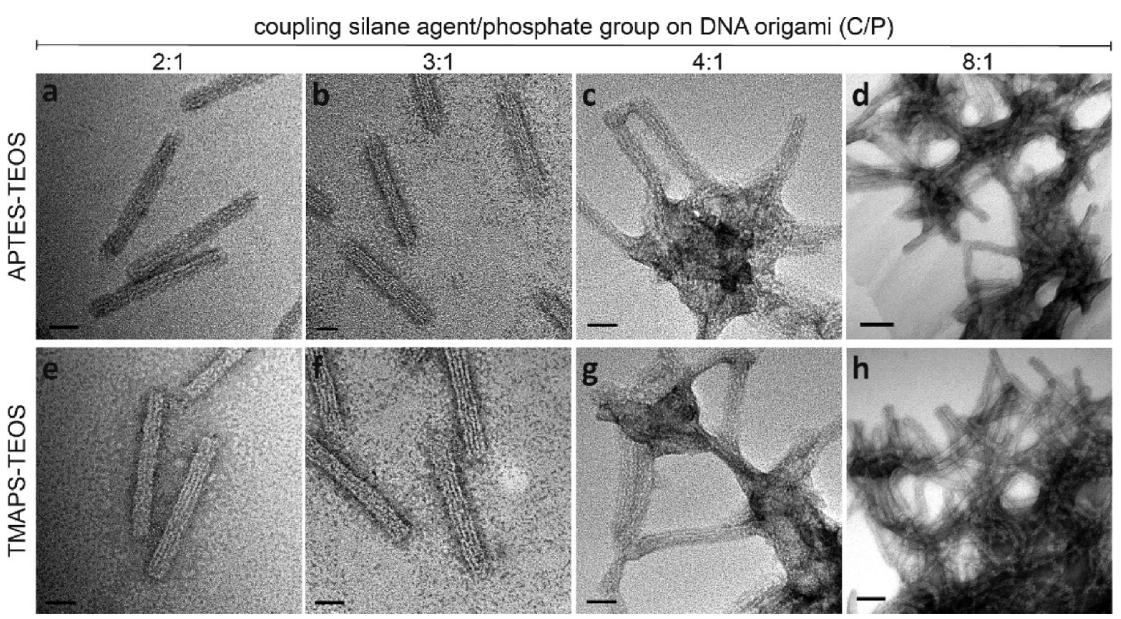

Figure 2. Silica growth on $12 \mathrm{nM} 24 \mathrm{HB}$ in aqueous solution of $15 \mathrm{mM} \mathrm{MgAc}$ under different molar ratios of C/P, T/P = 20:1, pH 9, and 5 day coating. Scale bars: $(\mathrm{a}-\mathrm{c}, \mathrm{e}-\mathrm{g}) 20 \mathrm{~nm} ;(\mathrm{d}, \mathrm{h}) 50 \mathrm{~nm}$.

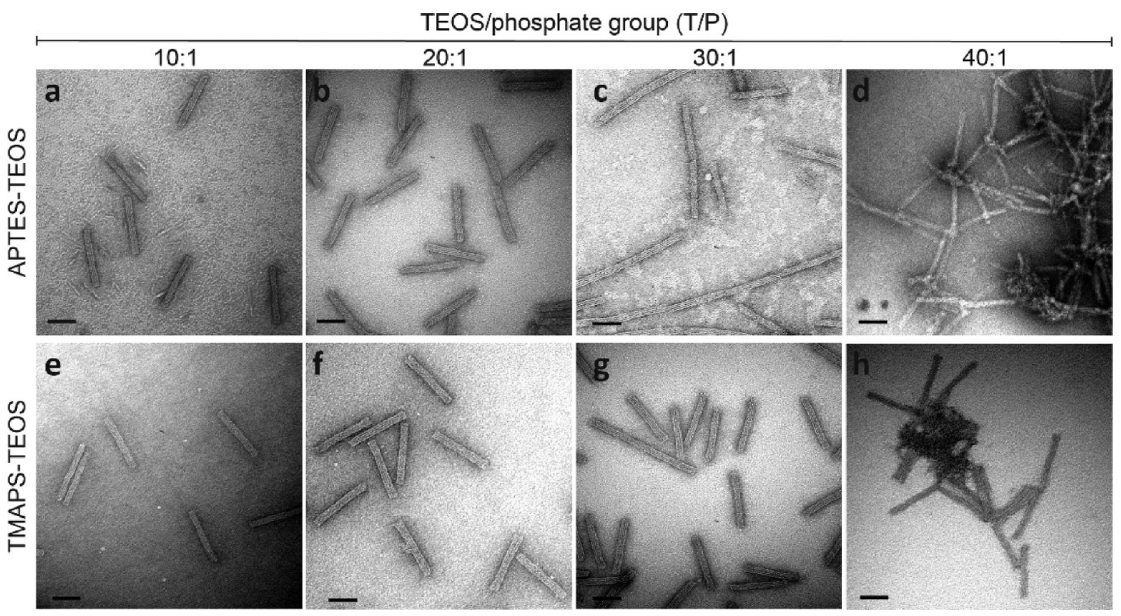

Figure 3. Silica growth of $12 \mathrm{nM} 24 \mathrm{HB}$ in an aqueous solution of $15 \mathrm{mM} \mathrm{MgAc}$ under different molar ratios of $\mathrm{T} / \mathrm{P}, \mathrm{C} / \mathrm{P}=3: 1, \mathrm{pH} 9$, and a 5 day coating. Scale bars: $50 \mathrm{~nm}$.

increased accordingly. The core-free silica particles appeared at the $\mathrm{T} / \mathrm{P}$ ratio of $40: 1$. It is interesting to note that at the $\mathrm{T} / \mathrm{P}$ ratio of 30:1 rather specific tip-to-tip stacking is observed for both TMAPS-TEOS and APTES-TEOS (Figure 3c,g). At higher $\mathrm{T} / \mathrm{P}$ ratio, the $24 \mathrm{HB}$ formed agglomerates not only through tip-to-tip stacking but also through side-to-side binding. Guided by the results presented in Figure 3, we chose the $\mathrm{T} / \mathrm{P}$ ratio of $20: 1$ for further experiments.

Next, we tested the influence of DNA origami concentration on the silica growth process. The concentration of $24 \mathrm{HB}$ was varied between 2 and $20 \mathrm{nM}$, keeping the $\mathrm{C} / \mathrm{P}$ and $\mathrm{T} / \mathrm{P}$ ratios fixed at 3:1 and 20:1, respectively. The results in Figure S6 indicate that the concentration of DNA origami template strongly affects the growth rate of silica layers. Although constant ratios of $\mathrm{C} / \mathrm{P}$ and $\mathrm{T} / \mathrm{P}$ were used, the concentrations of coupling agents and TEOS changed according to the concentration of origami. Higher concentrations of 24HB, coupling agents, and TEOS resulted in fast condensation and aggregation (Figure S6f, $\mathrm{f}^{\prime}$ ). At low concentrations of $24 \mathrm{HB}$, coupling agents, and TEOS, the effective interaction between the origami structure and the silica precursors was reduced, leading to the formation of free silica gel (Figure S6a, $\mathrm{a}^{\prime}$ ). Interestingly, the APTES-TEOS silica coating was more sensitive to concentration of origami than TMAPS-TEOS.
With the investigated ratios of $\mathrm{C} / \mathrm{P}, \mathrm{T} / \mathrm{P}$, and $\mathrm{pH}$, the suitable concentrations of DNA origami which results in well-dispersed structures are 12-14 and 6-16 nM for APTES-TEOS and TMAPS-TEOS, respectively. It has been reported that screening of negative charges on DNA origami by $\mathrm{Mg}^{2+}$ ions in buffers prevents efficient interaction of coupling agent with DNA. ${ }^{55-58}$ We tested whether reduced $\mathrm{Mg}^{2+}$ concentration (0.2 $\mathrm{mM})$ would lead to better results in comparison to 15 $\mathrm{mM} \mathrm{Mg}{ }^{2+}$ used throughout the study (Figures S7 and S8). After a 5 day coating with APTES-TEOS in aqueous solution of $0.2 \mathrm{mM} \mathrm{MgAc}$, the $24 \mathrm{HB}$ structures expanded, especially at the tips. Most of the TMAPS-TEOS-coated 24HB structures were broken. The internal structure of DNA origami was more disturbed by TMAPS than by APTES due to the stronger interaction of TMAPS with the phosphate groups of DNA backbone. The increased repulsion between DNA helices at a low $\mathrm{Mg}^{2+}$ concertation led to structural damage and deformation of DNA origami under the silicification process with TMAPS-TEOS and with APTES-TEOS, respectively.

Secondary Silica Coating in a Mutual Solvent. In a modified Stöber method, a mutual solvent of alcohol, e.g., isopropanol (IPA), and water is commonly used for the preparation of NPs' silica shells for two main reasons. ${ }^{78}$ The first is increased homogenization of precursors. The second is 


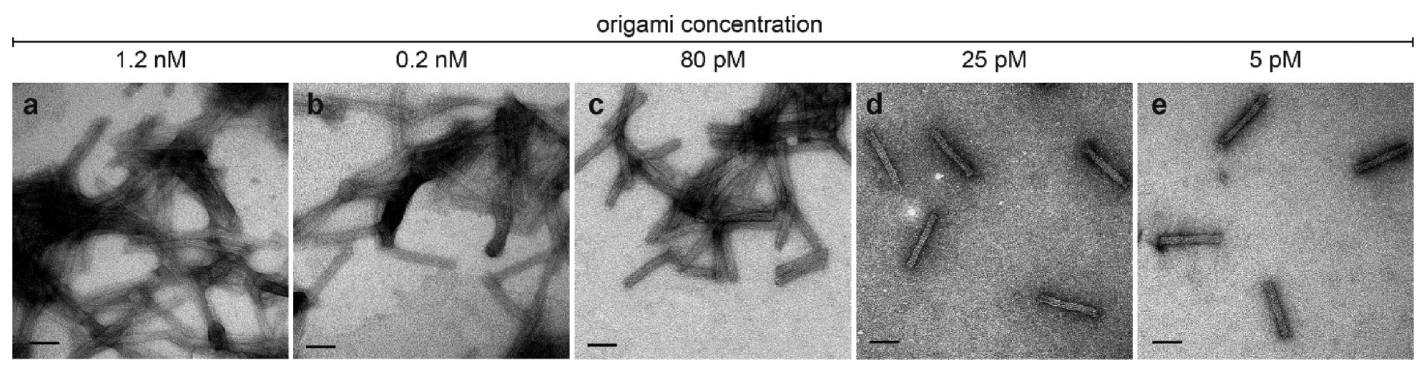

Figure 4. Secondary coating under different concentrations of purified $24 \mathrm{HB}$ DNA@SiO -1 in $20 \% \mathrm{v} / \mathrm{v}$ IPA aqueous solution for 24 h. Scale bars: $50 \mathrm{~nm}$.

the ability to control the rate of the hydrolysis-condensation reactions and an inorganic polymerization process with silica layers. DNA origami structures are not stable in IPA; hence, this solvent is not suitable for direct silica coating of origami constructs. However, the stability of DNA origami is promoted by the presence of silica shell after the primary coating in 15 $\mathrm{mM}$ MgAc solution, and the mixture of IPA and water can be used as solvent in the secondary silica coating on $\mathrm{DNA} @ \mathrm{SiO}_{2}-$ 1. Our previous works demonstrated that a solution of $80 \% \mathrm{v} / \mathrm{v}$ IPA in water was an optimum solvent for a silica coating on metallic NPs. ${ }^{79,80}$ To increase the hydrolysis of TEOS and fabricate smooth silica shells, an initial $\mathrm{pH}$ range of 10.8-11.4 has been applied in many studies. ${ }^{80-83}$ Herein, we investigated various percentages of IPA for the secondary coating process at $\mathrm{pH} 10.8$ for $24 \mathrm{~h}$ (Figure S9). Calculated amounts of IPA, TEOS, and $\mathrm{NH}_{4} \mathrm{OH}$ were added directly into the solution after a 5 day reaction of the primary coating process. Without IPA, silica gel cloud formed around DNA@SiO 2 structures (Figure S9a). After the addition of TEOS and IPA (from 20\% to $40 \%$ $\mathrm{v} / \mathrm{v}$ ), the formation of silica shells was clearly visible despite agglomeration (Figure S9b,c). With 80\% v/v IPA, large silica networks were formed (Figure S9d). Furthermore, addition of $40 \% \mathrm{v} / \mathrm{v}$ IPA without TEOS into the solution after a 5 day reaction of the primary coating also resulted in agglomeration of silica-coated 24HB (Figure S10a). The agglomeration is due to the IPA-induced complete hydrolysis of silica precursors and condensation of free silica clusters formed in the primary coating process. Interestingly, shaking at $500 \mathrm{rpm}$ during the silicification produced better results than the same rate stirring, which resulted in significant deformation of origami structures (Figure S10b). To gain better control of silica deposition during the secondary coating, we performed additional purification of DNA@ $@ \mathrm{SiO}_{2}-1$ after the primary coating (see the Supporting Information for purification of DNA@SiO 2$)$. To achieve ultrathin silica shells and monodisperse DNA@ $\mathrm{SiO}_{2}$, a solvent of $20 \% \mathrm{v} / \mathrm{v}$ IPA at $\mathrm{pH} 10.8$ and a T/P molar ratio of 5:1 were experimented for the secondary silica coating with various concentrations of purified 24HB DNA@SiO ${ }_{2}-1$ (Figure 4). Strong agglomeration was observed in samples with 24HB DNA@SiO $2-1$ concentrations above 80 pM due to the increased polymerization rate of silanol at high concentrations in a less polar IPA solution. The agglomeration was reduced by decreasing the concentration of DNA origami, and a welldispersed structure secondary silica coating (named DNA@ $\mathrm{SiO}_{2}-2$ ) was obtained at $25 \mathrm{pM}$ (Figure 4d). Silica layers after the coating were denser than after the primary coating (Figure S11), providing direct evidence that DNA origami structures are completely encapsulated with silica shells.

Application of the Silica Coating Protocols to $13 \mathrm{HR}$ DNA Origami. To validate our method, the protocols for the primary and secondary silica coatings were applied to ringshaped DNA origami structures consisting of 13 DNA helixes (13HR) with the outer diameter of $66 \mathrm{~nm}$ and the inner diameter of $46 \mathrm{~nm}$ (Figure 5). In contrast to the 24HB, the

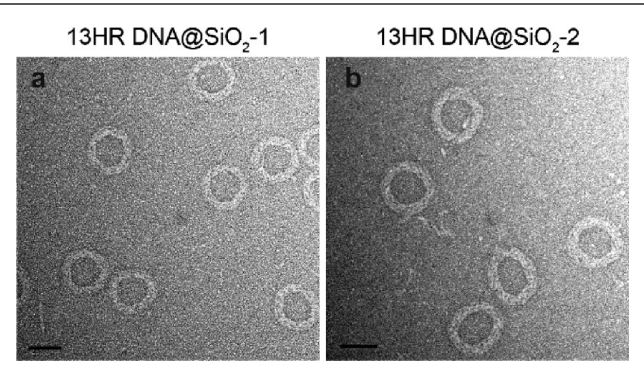

Figure 5. TEM characterization of $13 \mathrm{HR}$ structures after the silica coatings. (a) Primary coating process in $15 \mathrm{mM} \mathrm{MgAc}, \mathrm{pH} 9, \mathrm{C} / \mathrm{P}=$ $3: 1$, and $\mathrm{T} / \mathrm{P}=20: 1$ after 5 day coating (13HR DNA@SiO$\left.{ }_{2}-1\right)$. (b) Secondary coating process in IPA $20 \% \mathrm{v} / \mathrm{v}, \mathrm{pH} 10.8$, and $\mathrm{T} / \mathrm{P}=5: 1$ after 24 h coating (13HR DNA@ $\left.@ \mathrm{SiO}_{2}-2\right)$. Scale bars: $50 \mathrm{~nm}$.

13HR structures did not form agglomerates even after the 9 day primary silica coating process and were well dispersed in solution (Figure S12). This observation strongly confirms that the tip-to-tip stacking of $24 \mathrm{HB}$ is related to the flexibility and charge density of ssDNA at the short edges of origami constructs.

AFM Characterization of Silica Shell Thickness. The thickness of the silica shells after the primary and the secondary silica coatings was characterized by using AFM (Figure 6 and Figure S13). The height of both $24 \mathrm{HB}$ and $13 \mathrm{HR}$ increased after the coatings. The average heights $(N=$ 50 ) of the monodisperse nanostructures of $24 \mathrm{HB}, 24 \mathrm{HB}$ DNA@SiO 2 - and DNA 24HB $@ \mathrm{SiO}_{2}-2$ were $10.1 \pm 0.6,12.6$ \pm 0.6 , and $13.7 \pm 0.7 \mathrm{~nm}$, respectively (Figure $6 \mathrm{~d}$ ). The average heights $(N=50)$ of the 13HR, 13HR DNA@ $@ \mathrm{SiO}_{2}-1$ and 13HR DNA $@ \mathrm{SiO}_{2}-2$ were 5.2 \pm 0.5, 7.5 \pm 0.4 , and $8.1 \pm$ $0.4 \mathrm{~nm}$, respectively (Figure 6h). The AFM imaging confirmed the formation of silica shells and their nanoscale thickness.

Biochemical Stability Tests. To expand the utility of the DNA origami technique as the nanofabrication method, DNAorigami-based assemblies need to be stable under various conditions relevant to the fabrication and/or application procedures. Limited compatibility of DNA origami-based assemblies with solvents and biologically relevant fluids often restricts applications of the DNA origami technique. The stability of DNA origami structures in low magnesium buffers and resistance to degradation by nucleases are often prerequisites for biomedical applications. ${ }^{51-53}$ Encouraged by our results on stability at low $\mathrm{Mg}^{2+}$ concentration (Figure S6a), the exposure to DI water was tested on both $24 \mathrm{HB}$, i.e., bare 


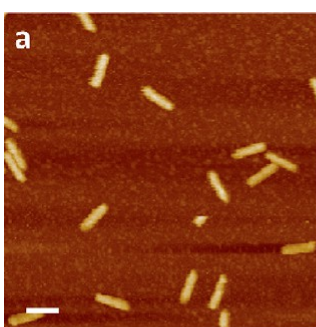

$24 \mathrm{HB}$

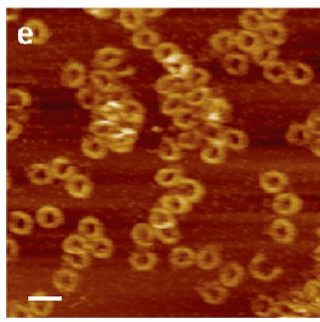

$13 \mathrm{HR}$

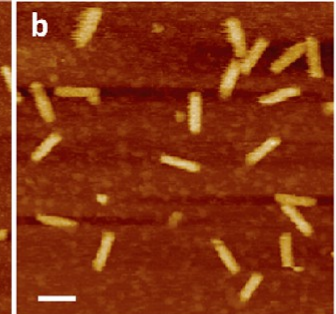

24HB DNA@SiO -1

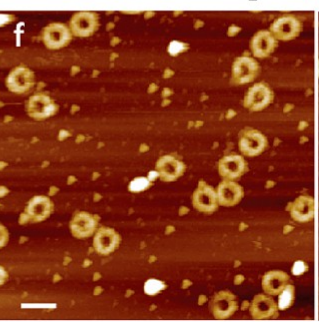

13HR DNA@SiO -1
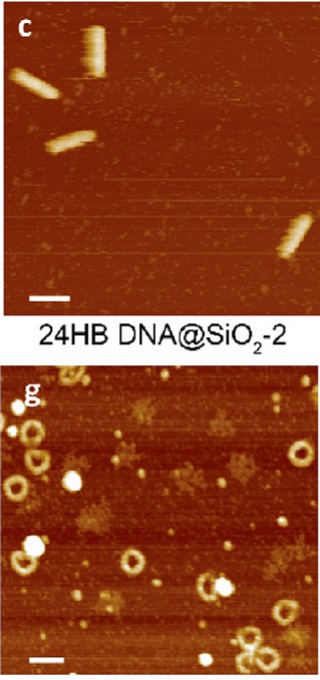

13HR DNA@SiO -2
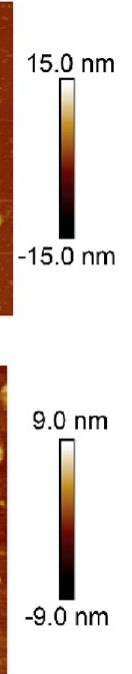
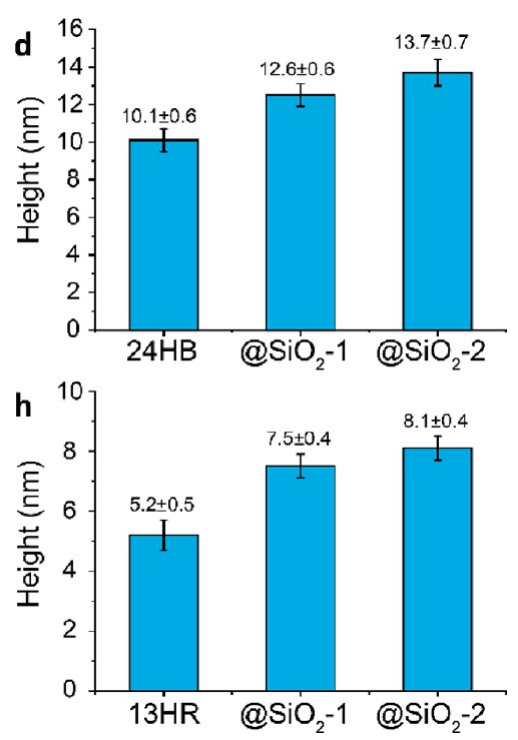

Figure 6. AFM characterization of DNA origami structures. (a-c, e-g) AFM images. Scale bars: $100 \mathrm{~nm}$. (d, h) Average heights of the 24HB and $13 \mathrm{HR}$, respectively, before and after the silica coating processes. Error bars: mean \pm s.d.
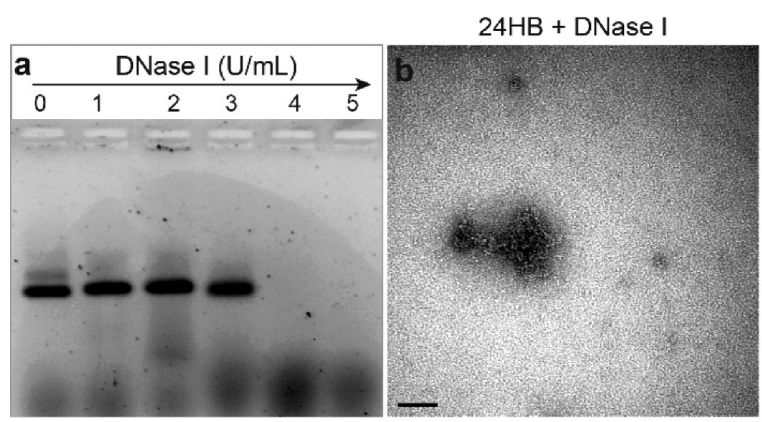

24HB DNA@SiO -1 + DNase I 24HB DNA@SiO -2 + DNase I
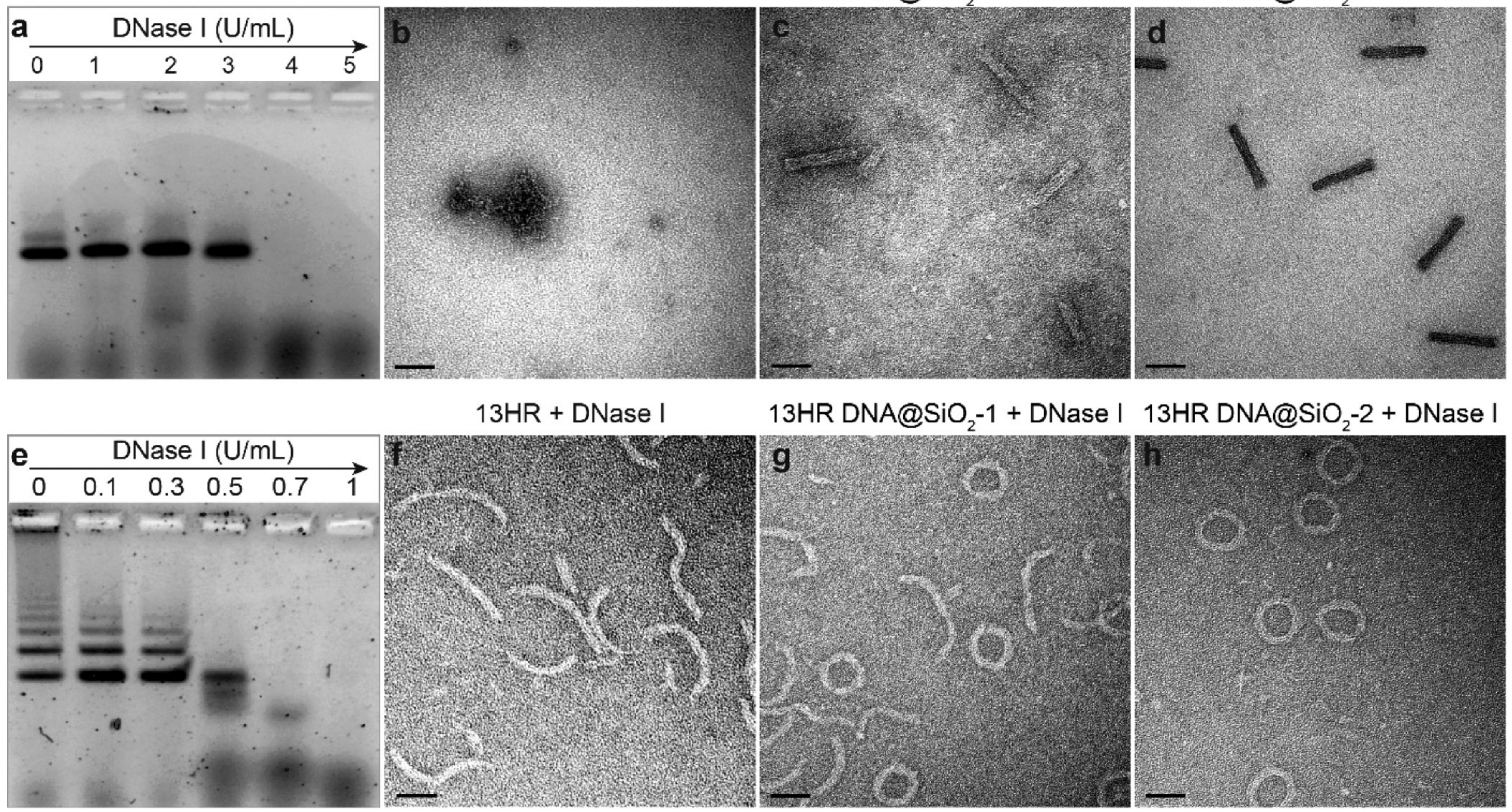

13HR DNA@SiO -1 + DNase I 13HR DNA@SiO -2 + DNase I

Figure 7. Resistance to the nuclease-mediated degradation of bare and encapsulated DNA origami structures. (a, e) DNase I titration assay for 24HB and 13HR, respectively. (b-d) Degradation of 24HB, 24HB DNA@SiO ${ }_{2}-1$, and 24HB DNA@SiO $2-2$, respectively, by $4 \mathrm{U} / \mathrm{mL} \mathrm{DNase} \mathrm{I}$. (fh) Degradation of $13 \mathrm{HR}, 13 \mathrm{HR}$ DNA@SiO ${ }_{2}-1$, and $13 \mathrm{HR} \mathrm{DNA} @ \mathrm{SiO}_{2}-2$, respectively, by $0.5 \mathrm{U} / \mathrm{mL}$ DNase I. The samples were incubated with DNase I for $3 \mathrm{~h}$ at $37{ }^{\circ} \mathrm{C}$. Scale bars: $50 \mathrm{~nm}$.

DNA origami, and 24HB DNA@SiO $2-1$, i.e., encapsulated structures. The $24 \mathrm{HB}$ were completely damaged after 1 week in DI water (Figure S14a). Because of the absence of $\mathrm{Mg}^{2+}$ ions, the repulsive electrostatic interactions between neighboring helices induced disintegration of origami structures. In contrast, after the primary coating, the 24HB DNA@SiO $2_{2}-1$ were stable in DI water for at least 10 months (Figure S14b). To evaluate the resistance to the nuclease-mediated degradation, we performed a DNase I titration assay, where uncoated $24 \mathrm{HB}$ and $13 \mathrm{HR}$ structures $(1 \mathrm{nM})$ were incubated with increasing amounts of enzyme in DNase I buffer for $3 \mathrm{~h}$ at 37 ${ }^{\circ} \mathrm{C}$. As observed by AGE and TEM (Figure 7a,e), bare $24 \mathrm{HB}$ structures were completely degraded at $4 \mathrm{U} / \mathrm{mL}$ of DNase I, and bare $13 \mathrm{HR}$ structures were significantly damaged in $0.5 \mathrm{U} /$ $\mathrm{mL}$ (Figure 7b,f). In contrast, the degradation of $\mathrm{DNA} @ \mathrm{SiO}_{2}-$ 1 structures was considerably reduced (Figure $7 \mathrm{c}, \mathrm{g}$ ). Remarkably, DNA@SiO 2 -2 structures resisted the degradation and maintained their structural integrity (Figure $7 \mathrm{~d}, \mathrm{~h}$ ). The increased stability after the secondary silica coating originates from both the increased thickness and the reduced porosity of silica shells.

We also evaluated stability of origami structures in a polar organic solvent, i.e., IPA, before and after the silica coating (Figure S14c,d). DNA origami constructs deposited on surfaces can preserve their structural integrity after exposure to certain organic solvents. ${ }^{54,84}$ However, applications of DNA 
origami technique in solution have almost exclusively relied on aqueous buffers, with a few exceptions. ${ }^{85}$ As expected, we did not observe any bare DNA origami structures in TEM after a 1 day exposure to IPA. However, after the primary silica coating, the 24HB DNA@SiO ${ }_{2}-1$ structures were stable in pure IPA for at least 3 days.

\section{CONCLUSIONS}

Through systematic screening of reaction conditions, we developed a method for coating of DNA origami structures with ultrathin silica shells in solution. Well-dispersed silicacoated structures were obtained by using APTES and TMAPS coupling agents that facilitated deposition of silica from TEOS. The TMAPS-TEOS coating was demonstrated to be successful with the wide range of $\mathrm{pH}$ and DNA origami concentration. On the other hand, the APTES-TEOS produced better results at low $\mathrm{Mg}^{2+}$ concentrations. In addition, we demonstrated that the density of silica shells can be improved with a secondary coating in a solution of $20 \%$ v/v IPA. Silica-coated DNA origami structures were stable against exposure to DI water and DNA nuclease. Furthermore, the structures were stable in pure IPA for several days, at least. The presented method can be easily adopted to origami constructs of various morphology, further advancing the utility of the DNA origami technique in nanofabrication and biomedical applications.

\section{ASSOCIATED CONTENT}

\section{SI Supporting Information}

The Supporting Information is available free of charge at https://pubs.acs.org/doi/10.1021/acs.chemmater.0c02111.

Staple sequences, strand routing diagrams, and TEM images of $24 \mathrm{HB}$ and 13HR; thermal annealing of DNA origamis; ionization states of APTES at a given solution $\mathrm{pH}$; influences of the coupling agents, origami, and MgAc concentrations on the silica coating on $24 \mathrm{HB}$; primary silica coating under static condition; secondary silica growth on $24 \mathrm{HB} \mathrm{DNA} @ \mathrm{SiO}_{2}-1$ under different IPA concentrations and mixing methods; TEM images of DNA@SiO 2 structures at the optimum conditions; histogram of the heights of $24 \mathrm{HB}$ and $13 \mathrm{HR}$ structures (with and without silica); stability of $24 \mathrm{HB}$ structures (with and without silica) in various solvents; purification of 24HBDNA@SiO -1 structures (PDF)

\section{AUTHOR INFORMATION}

\section{Corresponding Authors}

Minh-Kha Nguyen - Department of Neuroscience and Biomedical Engineering, Aalto University School of Science, FI00076 Aalto, Finland; Faculty of Chemical Engineering, HCMC University of Technology, VNU-HCM, Ho Chi Minh City 700000, Vietnam; o orcid.org/0000-0003-3456-3162; Email: kha.m.nguyen@aalto.fi

Anton Kuzyk - Department of Neuroscience and Biomedical Engineering, Aalto University School of Science, FI-00076 Aalto, Finland; (D) orcid.org/0000-0001-8060-6122;

Email: anton.kuzyk@aalto.fi

\section{Authors}

Vu Hoang Nguyen - Department of Neuroscience and Biomedical Engineering, Aalto University School of Science, FI00076 Aalto, Finland
Ashwin Karthick Natarajan - Department of Neuroscience and Biomedical Engineering, Aalto University School of Science, FI00076 Aalto, Finland; (1) orcid.org/0000-0001-7897-708X

Yike Huang - Department of Neuroscience and Biomedical Engineering, Aalto University School of Science, FI-00076 Aalto, Finland; (ㅇ orcid.org/0000-0003-2559-432X

Joonas Ryssy - Department of Neuroscience and Biomedical Engineering, Aalto University School of Science, FI-00076 Aalto, Finland; (1) orcid.org/0000-0001-9894-5050

Boxuan Shen - Department of Bioproducts and Biosystems, Aalto University School of Chemical Engineering, FI-00076 Aalto, Finland; (c) orcid.org/0000-0002-1107-828X

Complete contact information is available at:

https://pubs.acs.org/10.1021/acs.chemmater.0c02111

\section{Author Contributions}

K.N. and A.K. conceived the research and designed the experiments. V.N. and A.N. designed the DNA origami nanostructures. K.N. performed silica deposition experiments as well as TEM and AFM characterizations. B.S. and J.R. assisted with AFM imaging. Y.H. performed the gel electrophoresis experiments. A.K. and K.N. wrote the manuscript. All authors have given approval to the final version of the manuscript.

\section{Funding}

This work was supported by the Jane and Aatos Erkko Foundation and the Academy of Finland (Grants 308992 and 324352).

\section{Notes}

The authors declare no competing financial interest.

\section{ACKNOWLEDGMENTS}

The authors acknowledge the provision of facilities and technical support by Aalto University at the OtaNano Nanomicroscopy Center (Aalto-NMC). We thank R. Raju for his assistance with the AFM microscopy and S. Filonenko for the initial work on this project.

\section{REFERENCES}

(1) Marth, J. D. A Unified Vision of the Building Blocks of Life. Nat. Cell Biol. 2008, 10 (9), 1015-1015.

(2) Zhang, S. Fabrication of Novel Biomaterials through Molecular Self-Assembly. Nat. Biotechnol. 2003, 21 (10), 1171-1178.

(3) Seeman, N. C.; Sleiman, H. F. DNA Nanotechnology. Nat. Rev. Mater. 2018, 3 (1), 1-23.

(4) Madsen, M.; Gothelf, K. V. Chemistries for DNA Nanotechnology. Chem. Rev. 2019, 119 (10), 6384-6458.

(5) Rothemund, P. W. K. Folding DNA to Create Nanoscale Shapes and Patterns. Nature 2006, 440 (7082), 297-302.

(6) Hong, F.; Zhang, F.; Liu, Y.; Yan, H. DNA Origami: Scaffolds for Creating Higher Order Structures. Chem. Rev. 2017, 117 (20), 12584-12640.

(7) Wagenbauer, K. F.; Sigl, C.; Dietz, H. Gigadalton-Scale ShapeProgrammable DNA Assemblies. Nature 2017, 552 (7683), 78-83.

(8) Kuzyk, A.; Schreiber, R.; Fan, Z.; Pardatscher, G.; Roller, E.-M.; Högele, A.; Simmel, F. C.; Govorov, A. O.; Liedl, T. DNA-Based SelfAssembly of Chiral Plasmonic Nanostructures with Tailored Optical Response. Nature 2012, 483 (7389), 311-314.

(9) Schreiber, R.; Do, J.; Roller, E.-M.; Zhang, T.; Schüller, V. J.; Nickels, P. C.; Feldmann, J.; Liedl, T. Hierarchical Assembly of Metal Nanoparticles, Quantum Dots and Organic Dyes Using DNA Origami Scaffolds. Nat. Nanotechnol. 2014, 9 (1), 74-78.

(10) Acuna, G. P.; Möller, F. M.; Holzmeister, P.; Beater, S.; Lalkens, B.; Tinnefeld, P. Fluorescence Enhancement at Docking Sites 
of DNA-Directed Self-Assembled Nanoantennas. Science 2012, 338 (6106), 506-510.

(11) Kuzyk, A.; Schreiber, R.; Zhang, H.; Govorov, A. O.; Liedl, T.; Liu, N. Reconfigurable 3D Plasmonic Metamolecules. Nat. Mater. 2014, 13 (9), 862-866.

(12) Rinker, S.; Ke, Y.; Liu, Y.; Chhabra, R.; Yan, H. Self-Assembled DNA Nanostructures for Distance-Dependent Multivalent LigandProtein Binding. Nat. Nanotechnol. 2008, 3 (7), 418-422.

(13) Ke, Y.; Meyer, T.; Shih, W. M.; Bellot, G. Regulation at a Distance of Biomolecular Interactions Using a DNA Origami Nanoactuator. Nat. Commun. 2016, 7 (1), 1-8.

(14) Kuzyk, A.; Laitinen, K. T.; Törmä, P. DNA Origami as a Nanoscale Template for Protein Assembly. Nanotechnology 2009, 20 (23), 235305.

(15) Zhao, Z.; Fu, J.; Dhakal, S.; Johnson-Buck, A.; Liu, M.; Zhang, T.; Woodbury, N. W.; Liu, Y.; Walter, N. G.; Yan, H. Nanocaged Enzymes with Enhanced Catalytic Activity and Increased Stability against Protease Digestion. Nat. Commun. 2016, 7 (1), 10619.

(16) Woehrstein, J. B.; Strauss, M. T.; Ong, L. L.; Wei, B.; Zhang, D. Y.; Jungmann, R.; Yin, P. Sub-100-Nm Metafluorophores with Digitally Tunable Optical Properties Self-Assembled from DNA. Science Advances 2017, 3 (6), e1602128.

(17) Nicoli, F.; Barth, A.; Bae, W.; Neukirchinger, F.; Crevenna, A. H.; Lamb, D. C.; Liedl, T. Directional Photonic Wire Mediated by Homo-Förster Resonance Energy Transfer on a DNA Origami Platform. ACS Nano 2017, 11 (11), 11264-11272.

(18) Steinhauer, C.; Jungmann, R.; Sobey, T. L.; Simmel, F. C.; Tinnefeld, P. DNA Origami as a Nanoscopic Ruler for SuperResolution Microscopy. Angew. Chem., Int. Ed. 2009, 48 (47), 88708873.

(19) Tokura, Y.; Harvey, S.; Xu, X.; Chen, C.; Morsbach, S.; Wunderlich, K.; Fytas, G.; Wu, Y.; Ng, D. Y. W.; Weil, T. Polymer Tube Nanoreactors via DNA-Origami Templated Synthesis. Chem. Commun. 2018, 54 (22), 2808-2811.

(20) Knudsen, J. B.; Liu, L.; Bank Kodal, A. L.; Madsen, M.; Li, Q.; Song, J.; Woehrstein, J. B.; Wickham, S. F. J.; Strauss, M. T.; Schueder, F.; Vinther, J.; Krissanaprasit, A.; Gudnason, D.; Smith, A. A. A.; Ogaki, R.; Zelikin, A. N.; Besenbacher, F.; Birkedal, V.; Yin, P.; Shih, W. M.; Jungmann, R.; Dong, M.; Gothelf, K. V. Routing of Individual Polymers in Designed Patterns. Nat. Nanotechnol. 2015, 10 (10), 892-898.

(21) Helmi, S.; Ziegler, C.; Kauert, D. J.; Seidel, R. Shape-Controlled Synthesis of Gold Nanostructures Using DNA Origami Molds. Nano Lett. 2014, 14 (11), 6693-6698.

(22) Sun, W.; Boulais, E.; Hakobyan, Y.; Wang, W. L.; Guan, A.; Bathe, M.; Yin, P. Casting Inorganic Structures with DNA Molds. Science 2014, 346 (6210), 1258361.

(23) Shen, B.; Linko, V.; Tapio, K.; Pikker, S.; Lemma, T.; Gopinath, A.; Gothelf, K. V.; Kostiainen, M. A.; Toppari, J. J. Plasmonic Nanostructures through DNA-Assisted Lithography. Science Advances 2018, 4 (2), eaap8978.

(24) Jin, Z.; Sun, W.; Ke, Y.; Shih, C.-J.; Paulus, G. L. C.; Hua Wang, Q.; Mu, B.; Yin, P.; Strano, M. S. Metallized DNA Nanolithography for Encoding and Transferring Spatial Information for Graphene Patterning. Nat. Commun. 2013, 4, 1663.

(25) Keller, A.; Linko, V. Challenges and Perspectives of DNA Nanostructures in Biomedicine. Angew. Chem., Int. Ed. 2020, DOI: $10.1002 /$ anie.201916390.

(26) Ke, Y.; Castro, C.; Choi, J. H. Structural DNA Nanotechnology: Artificial Nanostructures for Biomedical Research. Annu. Rev. Biomed. Eng. 2018, 20 (1), 375-401.

(27) Kilchherr, F.; Wachauf, C.; Pelz, B.; Rief, M.; Zacharias, M.; Dietz, H. Single-Molecule Dissection of Stacking Forces in DNA. Science 2016, 353 (6304), aaf5508.

(28) Funke, J. J.; Ketterer, P.; Lieleg, C.; Schunter, S.; Korber, P.; Dietz, H. Uncovering the Forces between Nucleosomes Using DNA Origami. Science Advances 2016, 2 (11), el600974.

(29) Nickels, P. C.; Wünsch, B.; Holzmeister, P.; Bae, W.; Kneer, L. M.; Grohmann, D.; Tinnefeld, P.; Liedl, T. Molecular Force
Spectroscopy with a DNA Origami-Based Nanoscopic Force Clamp. Science 2016, 354 (6310), 305-307.

(30) Funck, T.; Nicoli, F.; Kuzyk, A.; Liedl, T. Sensing Picomolar Concentrations of RNA Using Switchable Plasmonic Chirality. Angew. Chem. 2018, 130 (41), 13683-13686.

(31) Huang, Y.; Nguyen, M.-K.; Natarajan, A. K.; Nguyen, V. H.; Kuzyk, A. A DNA Origami-Based Chiral Plasmonic Sensing Device. ACS Appl. Mater. Interfaces 2018, 10 (51), 44221-44225.

(32) Selnihhin, D.; Sparvath, S. M.; Preus, S.; Birkedal, V.; Andersen, E. S. Multifluorophore DNA Origami Beacon as a Biosensing Platform. ACS Nano 2018, 12 (6), 5699-5708.

(33) Ochmann, S. E.; Vietz, C.; Trofymchuk, K.; Acuna, G. P.; Lalkens, B.; Tinnefeld, P. Optical Nanoantenna for Single MoleculeBased Detection of Zika Virus Nucleic Acids without Molecular Multiplication. Anal. Chem. 2017, 89 (23), 13000-13007.

(34) Liu, N.; Liedl, T. DNA-Assembled Advanced Plasmonic Architectures. Chem. Rev. 2018, 118 (6), 3032-3053.

(35) Nguyen, M.-K.; Kuzyk, A. Reconfigurable Chiral Plasmonics beyond Single Chiral Centers. ACS Nano 2019, 13 (12), 1361513619.

(36) Zhou, C.; Duan, X.; Liu, N. DNA-Nanotechnology-Enabled Chiral Plasmonics: From Static to Dynamic. Acc. Chem. Res. 2017, 50 (12), 2906-2914.

(37) Bui, H.; Díaz, S. A.; Fontana, J.; Chiriboga, M.; Veneziano, R.; Medintz, I. L. Utilizing the Organizational Power of DNA Scaffolds for New Nanophotonic Applications. Adv. Opt. Mater. 2019, 7 (18), 1900562.

(38) Schlichthaerle, T.; Strauss, M. T.; Schueder, F.; Woehrstein, J. B.; Jungmann, R. DNA Nanotechnology and Fluorescence Applications. Curr. Opin. Biotechnol. 2016, 39, 41-47.

(39) Kuzyk, A.; Jungmann, R.; Acuna, G. P.; Liu, N. DNA Origami Route for Nanophotonics. ACS Photonics 2018, 5 (4), 1151-1163.

(40) Zhan, P.; Urban, M. J.; Both, S.; Duan, X.; Kuzyk, A.; Weiss, T.; Liu, N. DNA-Assembled Nanoarchitectures with Multiple Components in Regulated and Coordinated Motion. Science Advances 2019, 5 (11), eaax6023.

(41) Kopperger, E.; List, J.; Madhira, S.; Rothfischer, F.; Lamb, D. C.; Simmel, F. C. A Self-Assembled Nanoscale Robotic Arm Controlled by Electric Fields. Science 2018, 359 (6373), 296-301.

(42) Li, S.; Jiang, Q.; Liu, S.; Zhang, Y.; Tian, Y.; Song, C.; Wang, J.; Zou, Y.; Anderson, G. J.; Han, J.-Y.; Chang, Y.; Liu, Y.; Zhang, C.; Chen, L.; Zhou, G.; Nie, G.; Yan, H.; Ding, B.; Zhao, Y. A DNA Nanorobot Functions as a Cancer Therapeutic in Response to a Molecular Trigger in Vivo. Nat. Biotechnol. 2018, 36 (3), 258-264.

(43) Hu, Q.; Li, H.; Wang, L.; Gu, H.; Fan, C. DNA Nanotechnology-Enabled Drug Delivery Systems. Chem. Rev. 2018, 119 (10), 6459-6506.

(44) Hu, Y.; Niemeyer, C. M. From DNA Nanotechnology to Material Systems Engineering. Adv. Mater. 2019, 31 (26), 1806294.

(45) Wang, P.; Meyer, T. A.; Pan, V.; Dutta, P. K.; Ke, Y. The Beauty and Utility of DNA Origami. Chem. 2017, 2 (3), 359-382.

(46) Pinheiro, A. V.; Han, D.; Shih, W. M.; Yan, H. Challenges and Opportunities for Structural DNA Nanotechnology. Nat. Nanotechnol. 2011, 6 (12), 763-772.

(47) Gerling, T.; Kube, M.; Kick, B.; Dietz, H. SequenceProgrammable Covalent Bonding of Designed DNA Assemblies. Science Advances 2018, 4 (8), eaau1157.

(48) Mikkilä, J.; Eskelinen, A.-P.; Niemelä, E. H.; Linko, V.; Frilander, M. J.; Törmä, P.; Kostiainen, M. A. Virus-Encapsulated DNA Origami Nanostructures for Cellular Delivery. Nano Lett. 2014, 14 (4), 2196-2200.

(49) Auvinen, H.; Zhang, H.; Nonappa; Kopilow, A.; Niemelä, E. H.; Nummelin, S.; Correia, A.; Santos, H. A.; Linko, V.; Kostiainen, M. A. Protein Coating of DNA Nanostructures for Enhanced Stability and Immunocompatibility. Adv. Healthcare Mater. 2017, 6 (18), 1700692.

(50) Kiviaho, J. K.; Linko, V.; Ora, A.; Tiainen, T.; Jarvihaavisto, E.; Mikkila, J.; Tenhu, H.; Nonappa, N.; Kostiainen, M. A. Cationic Polymers for DNA Origami Coating - Examining Their Binding 
Efficiency and Tuning the Enzymatic Reaction Rates. Nanoscale 2016, 8 (22), 11674-11680.

(51) Agarwal, N. P.; Matthies, M.; Gür, F. N.; Osada, K.; Schmidt, T. L. Block Copolymer Micellization as a Protection Strategy for DNA Origami. Angew. Chem., Int. Ed. 2017, 56 (20), 5460-5464.

(52) Ponnuswamy, N.; Bastings, M. M. C.; Nathwani, B.; Ryu, J. H.; Chou, L. Y. T.; Vinther, M.; Li, W. A.; Anastassacos, F. M.; Mooney, D. J.; Shih, W. M. Oligolysine-Based Coating Protects DNA Nanostructures from Low-Salt Denaturation and Nuclease Degradation. Nat. Commun. 2017, 8, 15654.

(53) Anastassacos, F. M.; Zhao, Z.; Zeng, Y.; Shih, W. M. Glutaraldehyde Cross-Linking of Oligolysines Coating DNA Origami Greatly Reduces Susceptibility to Nuclease Degradation. J. Am. Chem. Soc. 2020, 142 (7), 3311-3315.

(54) Kim, H.; Surwade, S. P.; Powell, A.; O’Donnell, C.; Liu, H. Stability of DNA Origami Nanostructure under Diverse Chemical Environments. Chem. Mater. 2014, 26 (18), 5265-5273.

(55) Nguyen, L.; Döblinger, M.; Liedl, T.; Heuer-Jungemann, A. DNA-Origami-Templated Silica Growth by Sol-Gel Chemistry. Angew. Chem., Int. Ed. 2019, 58 (3), 912-916.

(56) Liu, X.; Zhang, F.; Jing, X.; Pan, M.; Liu, P.; Li, W.; Zhu, B.; Li, J.; Chen, H.; Wang, L.; Lin, J.; Liu, Y.; Zhao, D.; Yan, H.; Fan, C. Complex Silica Composite Nanomaterials Templated with DNA Origami. Nature 2018, 559 (7715), 593.

(57) Jing, X.; Zhang, F.; Pan, M.; Dai, X.; Li, J.; Wang, L.; Liu, X.; Yan, H.; Fan, C. Solidifying Framework Nucleic Acids with Silica. Nat. Protoc. 2019, 14, 2416.

(58) Shang, Y.; Li, N.; Liu, S.; Wang, L.; Wang, Z.-G.; Zhang, Z.; Ding, B. Site-Specific Synthesis of Silica Nanostructures on DNA Origami Templates. Adv. Mater. 2020, 32, 2000294.

(59) Douglas, S. M.; Marblestone, A. H.; Teerapittayanon, S.; Vazquez, A.; Church, G. M.; Shih, W. M. Rapid Prototyping of 3D DNA-Origami Shapes with CaDNAno. Nucleic Acids Res. 2009, 37 (15), 5001-5006.

(60) Stahl, E.; Martin, T. G.; Praetorius, F.; Dietz, H. Facile and Scalable Preparation of Pure and Dense DNA Origami Solutions. Angew. Chem., Int. Ed. 2014, 53 (47), 12735-12740.

(61) Huang, Y.; Nguyen, M.-K.; Kuzyk, A. Assembly of Gold Nanorods into Chiral Plasmonic Metamolecules Using DNA Origami Templates. J. Visualized Exp. 2019, No. 145, e59280.

(62) Paunescu, D.; Puddu, M.; Soellner, J. O. B.; Stoessel, P. R.; Grass, R. N. Reversible DNA Encapsulation in Silica to Produce ROSResistant and Heat-Resistant Synthetic DNA "Fossils. Nat. Protoc. 2013, 8 (12), 2440-2448.

(63) Delclos, T.; Aimé, C.; Pouget, E.; Brizard, A.; Huc, I.; Delville, M.-H.; Oda, R. Individualized Silica Nanohelices and Nanotubes: Tuning Inorganic Nanostructures Using Lipidic Self-Assemblies. Nano Lett. 2008, 8 (7), 1929-1935.

(64) Cao, Y.; Xie, J.; Liu, B.; Han, L.; Che, S. Synthesis and Characterization of Multi-Helical DNA-Silica Fibers. Chem. Commun. 2013, 49 (11), 1097-1099.

(65) Paunescu, D.; Fuhrer, R.; Grass, R. N. Protection and Deprotection of DNA-High-Temperature Stability of Nucleic Acid Barcodes for Polymer Labeling. Angew. Chem., Int. Ed. 2013, 52 (15), $4269-4272$.

(66) Auyeung, E.; Macfarlane, R. J.; Choi, C. H. J.; Cutler, J. I.; Mirkin, C. A. Transitioning DNA-Engineered Nanoparticle Superlattices from Solution to the Solid State. Adv. Mater. 2012, 24 (38), 5181-5186.

(67) Albert, K.; Huang, X.-C.; Hsu, H.-Y. Bio-Templated Silica Composites for next-Generation Biomedical Applications. Adv. Colloid Interface Sci. 2017, 249, 272-289.

(68) Kuzyk, A.; Urban, M. J.; Idili, A.; Ricci, F.; Liu, N. Selective Control of Reconfigurable Chiral Plasmonic Metamolecules. Science Advances 2017, 3 (4), e1602803.

(69) Burggraaf, A. J. In Membrane Science and Technology; Burggraaf, A. J., Cot, L., Eds.; Fundamentals of Inorganic Membrane Science and Technology; Elsevier: 1996; Vol. 4, Chapter 8, pp 259-329.
(70) van der Maaden, K.; Sliedregt, K.; Kros, A.; Jiskoot, W.; Bouwstra, J. Fluorescent Nanoparticle Adhesion Assay: A Novel Method for Surface PKa Determination of Self-Assembled Monolayers on Silicon Surfaces. Langmuir 2012, 28 (7), 3403-3411.

(71) Chiu, S.-J.; Wang, S.-Y.; Chou, H.-C.; Liu, Y.-L.; Hu, T.-M. Versatile Synthesis of Thiol- and Amine-Bifunctionalized Silica Nanoparticles Based on the Ouzo Effect. Langmuir 2014, 30 (26), 7676-7686.

(72) Castro, C. E.; Kilchherr, F.; Kim, D.-N.; Shiao, E. L.; Wauer, T.; Wortmann, P.; Bathe, M.; Dietz, H. A Primer to Scaffolded DNA Origami. Nat. Methods 2011, 8 (3), 221-229.

(73) Ambia-Garrido, J.; Vainrub, A.; Pettitt, B. M. A Model for Structure and Thermodynamics of SsDNA and DsDNA near a Surface: A Coarse Grained Approach. Comput. Phys. Commun. 2010, 181 (12), 2001-2007.

(74) Liz-Marzán, L. M.; Giersig, M.; Mulvaney, P. Synthesis of Nanosized Gold-Silica Core-Shell Particles. Langmuir 1996, 12 (18), 4329-4335.

(75) Ding, H. L.; Zhang, Y. X.; Wang, S.; Xu, J. M.; Xu, S. C.; Li, G. H. $\mathrm{Fe}_{3} \mathrm{O}_{4} @ \mathrm{SiO}_{2}$ Core/Shell Nanoparticles: The Silica Coating Regulations with a Single Core for Different Core Sizes and Shell Thicknesses. Chem. Mater. 2012, 24 (23), 4572-4580.

(76) Kobayashi, Y.; Inose, H.; Nakagawa, T.; Gonda, K.; Takeda, M.; Ohuchi, N.; Kasuya, A. Control of Shell Thickness in SilicaCoating of Au Nanoparticles and Their X-Ray Imaging Properties. J. Colloid Interface Sci. 2011, 358 (2), 329-333.

(77) Nguyen, M.-K.; Su, W.-N.; Chen, C.-H.; Rick, J.; Hwang, B.-J. Highly Sensitive and Stable $\mathrm{Ag} @ \mathrm{SiO}_{2}$ Nanocubes for Label-Free SERS-Photoluminescence Detection of Biomolecules. Spectrochim. Acta, Part A 2017, 175, 239-245.

(78) Liberman, A.; Mendez, N.; Trogler, W. C.; Kummel, A. C. Synthesis and Surface Functionalization of Silica Nanoparticles for Nanomedicine. Surf. Sci. Rep. 2014, 69 (2), 132-158.

(79) Kha, N. M.; Chen, C.-H.; Su, W.-N.; Rick, J.; Hwang, B.-J. Improved Raman and Photoluminescence Sensitivity Achieved Using Bifunctional Ag@SiO 2 Nanocubes. Phys. Chem. Chem. Phys. 2015, 17 (33), 21226-21235.

(80) Nguyen, M.-K.; Su, W.-N.; Hwang, B.-J. A Plasmonic Coupling Substrate Based on Sandwich Structure of Ultrathin Silica-Coated Silver Nanocubes and Flower-Like Alumina-Coated Etched Aluminum for Sensitive Detection of Biomarkers in Urine. Adv. Healthcare Mater. 2017, 6 (10), 1601290.

(81) Chen, Y.-S.; Frey, W.; Kim, S.; Kruizinga, P.; Homan, K.; Emelianov, S. Silica-Coated Gold Nanorods as Photoacoustic Signal Nanoamplifiers. Nano Lett. 2011, 11 (2), 348-354.

(82) Pastoriza-Santos, I.; Pérez-Juste, J.; Liz-Marzán, L. M. SilicaCoating and Hydrophobation of CTAB-Stabilized Gold Nanorods. Chem. Mater. 2006, 18 (10), 2465-2467.

(83) Wang, J.; Sugawara-Narutaki, A.; Fukao, M.; Yokoi, T.; Shimojima, A.; Okubo, T. Two-Phase Synthesis of Monodisperse Silica Nanospheres with Amines or Ammonia Catalyst and Their Controlled Self-Assembly. ACS Appl. Mater. Interfaces 2011, 3 (5), $1538-1544$

(84) Hung, A. M.; Micheel, C. M.; Bozano, L. D.; Osterbur, L. W.; Wallraff, G. M.; Cha, J. N. Large-Area Spatially Ordered Arrays of Gold Nanoparticles Directed by Lithographically Confined DNA Origami. Nat. Nanotechnol. 2010, 5 (2), 121-126.

(85) Gállego, I.; Grover, M. A.; Hud, N. V. Folding and Imaging of DNA Nanostructures in Anhydrous and Hydrated Deep-Eutectic Solvents. Angew. Chem., Int. Ed. 2015, 54 (23), 6765-6769. 